\title{
Impact of Altered Alveolar Volume on the Diffusing Capacity of the Lung for Carbon Monoxide in Obesity
}

\author{
Irina Enache ${ }^{a}$ Monique Oswald-Mammosser ${ }^{a} \quad$ Stéphanie Scarfone ${ }^{a}$ \\ Chantal Simon $^{b}$ Jean-Louis Schlienger ${ }^{b}$ Bernard Geny ${ }^{a}$ Anne Charloux ${ }^{a}$ \\ a Service de Physiologie et d'Explorations Fonctionnelles, Pôle de Pathologie Thoracique, Hôpitaux Universitaires \\ de Strasbourg, et EA 3072, Institut de Physiologie, Faculté de Médecine, et b Service de Médecine Interne et \\ Nutrition, Hôpital de Hautepierre, Hôpitaux Universitaires de Strasbourg, Strasbourg, France
}

\section{Key Words}

Alveolar volume $\cdot$ Body mass index $\cdot$ Diffusion capacity of the lung $\cdot$ Lung volume $\cdot$ Obesity $\cdot$ Waist circumference

\begin{abstract}
Background: Studies on the diffusing capacity of the lung for carbon monoxide ( $\mathrm{D} \mathrm{L}_{\mathrm{CO}}$ ) in obese patients are conflicting, some studies showing increased $\mathrm{D}_{\mathrm{CO}}$ and others unaltered or reduced values in these subjects. Objectives: To compare obese patients to controls, examine the contribution of alveolar volume $\left(V_{A}\right)$ and $C O$ transfer coefficient $\left(\mathrm{K}_{\mathrm{CO}}\right)$ to $\mathrm{DL}_{\mathrm{CO}}$, and calculate $D L_{C O}$ values adjusted for VA. Methods: We measured body mass index (BMI), waist circumference (WC), spirometry and $\mathrm{DL}_{\mathrm{CO}}$ in 98 adult obese patients without cardiopulmonary or smoking history and 48 healthy subjects. All tests were performed in the same laboratory. Results: Using conventional reference values, mean $D \mathrm{~L}_{\mathrm{CO}}$ and $V_{A}$ were lower $\left(-6 \%, p<0.05\right.$, and $-13 \%, p<0.001$, respectively), and $\mathrm{K}_{\mathrm{CO}}$ was higher $(+9 \%, p<0.05)$ in obese patients than in controls. $V_{A}$ decreased whereas $K_{C O}$ increased with increasing BMI and $W C$ in the obese group. Patients with lower $\mathrm{DL}_{\mathrm{CO}}$ had low $\mathrm{K}_{\mathrm{CO}}$ in addition to decreased $V A$. In contrast, some obese patients maintained normal $V_{A}$, which, coupled with high $\mathrm{K}_{\mathrm{CO}}$, result-
\end{abstract}

ed in higher $\mathrm{DL}_{\mathrm{CO}}$. The main result is that diffusion capacity differences between obese patients and controls disappeared using reference equations adjusting $\mathrm{DL}_{\mathrm{CO}}$ for VA. Conclusions: Using conventional reference equations, our obese patients show slightly lower mean $\mathrm{D}_{\mathrm{CO}}$, lower mean $\mathrm{V}_{\mathrm{A}}$ and higher mean $\mathrm{K}_{\mathrm{CO}}$ than controls, but with a large range of $\mathrm{DL} \mathrm{LOO}_{\mathrm{CO}}$ values and patterns. Adjusting $\mathrm{DL}_{\mathrm{CO}}$ for VA suggests that low lung volumes are the main cause of low $\mathrm{D}_{\mathrm{CO}}$ and high $\mathrm{K}_{\mathrm{CO}}$ values in obese patients.

Copyright @ 2010 S. Karger AG, Basel

\section{Introduction}

The impairment of the respiratory function in obesity has long been recognized [1]. However, while the effects of obesity on spirometric variables are well established, studies on the diffusing capacity of the lung for carbon monoxide $\left(\mathrm{DL}_{\mathrm{CO}}\right)$ in obese patients are conflicting. Some studies found increased $\mathrm{DL}_{\mathrm{CO}}$ values [2-4]. In contrast, others found that $\mathrm{DL}_{\mathrm{CO}}$ was unaltered or reduced in obese subjects [5-10]. The earliest study concluded that, in the case of low-normal $\mathrm{DL}_{\mathrm{CO}}$, loss of the pulmonary capillary bed should be suspected in obese patients [3]. Part of

\section{KARGER}

Fax +4161306 1234

E-Mail karger@karger.ch

www.karger.com (c) 2010 S. Karger AG, Basel

$0025-7931 / 11 / 0813-0217 \$ 38.00 / 0$

Accessible online at:

www.karger.com/res
Anne Charloux, Service de Physiologie et d'Explorations Fonctionnelles

Pôle de Pathologie Thoracique, Hôpitaux Universitaires, BP 426

FR-67091 Strasbourg Cedex (France)

Tel. +33 36955 0879, Fax +33 369551826

E-Mail Anne.Charloux@chru-strasbourg.fr 
these discrepancies may be explained by the lack of control subjects in some of these series, the measured $\mathrm{DL}_{\mathrm{CO}}$ being compared to predicted values. In addition, medical history, especially smoking history, was not taken into account in all studies.

The calculation of single-breath $\mathrm{DL}_{\mathrm{CO}}$ requires measurement of two variables, the permeability factor $(\mathrm{kCO}$, Krogh factor) and the alveolar volume (VA). $\mathrm{kCO}$ is measured as the exponential decay in fractional concentration of $\mathrm{CO}$ over the breath-holding period. VA is measured using the gas dilution method. The $\mathrm{kCO}$ converts to $\mathrm{K}_{\mathrm{CO}}$ or $\mathrm{DL}_{\mathrm{CO}} / \mathrm{VA}$ by dividing by the STPD to BTPS conversion and by the barometric pressure term, and $\mathrm{DL}_{\mathrm{CO}}$ is the product of $\mathrm{K}_{\mathrm{CO}}$ and VA [11]. Consequently, low $\mathrm{DL}_{\mathrm{CO}}$ results from low $\mathrm{K}_{\mathrm{CO}}$ and/or low VA. Only a few studies on obesity reported $\mathrm{K}_{\mathrm{CO}}$ and/or VA values $[2,4,5,10]$. Interpreting these variables in obese patients should contribute to understanding the discrepancies between the published studies, and identifying the role of low lung volumes [6] or increased $\mathrm{K}_{\mathrm{CO}}[2,3]$ in $\mathrm{DL}_{\mathrm{CO}}$ variations. Furthermore, the low VA values observed in some series can also explain at least part of the high $\mathrm{K}_{\mathrm{CO}}$ reported in some obese patients. In normal subjects, $\mathrm{K}_{\mathrm{CO}}$ increases when VA decreases. Consequently, $\mathrm{DL}_{\mathrm{CO}}$ is lower and $\mathrm{K}_{\mathrm{CO}}$ is higher at lower lung volumes compared with reference values estimated at total lung capacity $[12,13]$. Reference equations have been published to adjust $\mathrm{DL}_{\mathrm{CO}}$ and $\mathrm{K}_{\mathrm{CO}}$ for lung volume [12-16]. Obtaining normal $\mathrm{DL}_{\mathrm{CO}}$ values with these equations would support that $\mathrm{DL}_{\mathrm{CO}}$ changes in obese patients result mainly from altered lung volumes.

Considering the above, the aims of this study were: (i) to compare the $\mathrm{DL}_{\mathrm{CO}}$ of obese patients to those of controls obtained in the same laboratory; (ii) to examine the contribution of $\mathrm{VA}$ and $\mathrm{K}_{\mathrm{CO}}$ to $\mathrm{DL}_{\mathrm{CO}}$ values, especially in obese patients with higher $\mathrm{DL}_{\mathrm{CO}}$ or lower $\mathrm{DL}_{\mathrm{CO}}$, and (iii) to compare the $\mathrm{DL}_{\mathrm{CO}}$ values of obese patients to reference values adjusted for VA.

\section{Subjects and Methods}

We retrospectively reviewed the medical records of adult patients ( $>18$ years) who were referred to our department for pulmonary function tests before weight reduction surgery between January 2003 and June 2008. Patients were reassessed in our department. Patients with smoking history, diabetes, obesity hypoventilation syndrome, cardiopulmonary and chest wall abnormalities, revealed by a complete medical history, physical examination and chest radiograph, were excluded.

Control subjects were technicians, nurses, physicians or students from our department, and healthy subjects referred for assessment before exercise training protocols. All of them denied cardiopulmonary history or symptoms and smoking history, and allowed us verbally to put their data in our database in an anonymous manner. This study has been approved by the Institutional Review Board of the French Learned Society for Respiratory Medicine - Société de Pneumologie de Langue Française (CEPRO 2008-022).

\section{Pulmonary Function Tests}

Lung volumes, flow-volume curves and single-breath $\mathrm{DL}_{\mathrm{CO}}$ tests were measured using a MS-PFT device (Jaeger USA Masterscreen Diffusion TP, VIASYS Healthcare, Yorba Linda, Calif., USA), and following the ATS/ERS recommendations [17-20]. Functional residual capacity was determined using the helium dilution technique. For DL $\mathrm{L}_{\mathrm{CO}}$ measurement, we paid particular attention to equipment quality control and test acceptability [18]. Equipment and protocols were unchanged during the 5.5-year period and tests were performed by experienced technicians. Reference equations for spirometry and $\mathrm{DL}_{\mathrm{CO}}$ used in our laboratory are those published by the European Respiratory Society in 1993 $[17,21]$. Predicted VA is predicted total lung capacity - anatomic dead space $(150 \mathrm{ml})[17,18]$. Reference values used to adjust $\mathrm{DL}_{\mathrm{CO}}$ or $\mathrm{K}_{\mathrm{CO}}$ for VA are those published by Chinn et al. [14], Frans et al. [12], Johnson [16], Stam et al. [13] and Filley et al. [15]. DL $\mathrm{CO}_{\mathrm{CO}}$ values of patients were corrected for hemoglobin $(\mathrm{Hb})$ [18]. Results are expressed as absolute values and percentage of predicted values.

Height and weight were measured and body mass index (BMI) was calculated. Waist circumference (WC) was quantified by placing a measuring tape around the waist at the midpoint between the lowest rib margin and the upper point of the iliac crest at the end of expiration. WC was measured by experienced personnel from the Internal Medicine and Nutrition Department.

\section{Analysis}

Student's t test was used to compare the variables of patients and controls. One-way analysis of variance (ANOVA) was performed to compare $\mathrm{DL}_{\mathrm{CO}} \%, \mathrm{~K}_{\mathrm{CO}} \%$ or $\mathrm{VA} \%$ of controls and obese patients grouped by $\mathrm{DL}_{\mathrm{CO}} \%$ (>mean $\mathrm{DL}_{\mathrm{CO}} \%$ of the control group or $<90 \%$ mean $\mathrm{DL}_{\mathrm{CO}} \%$ of the control group). When the $\mathrm{F}$ value indicated significant differences, a Student-Neuman-Keuls test for multiple comparisons was performed. Linear regression between $\mathrm{DL}_{\mathrm{CO}} \%, \mathrm{~K}_{\mathrm{CO}} \%$ or VA\% and either BMI or WC were assessed, and the Pearson correlation coefficients were calculated. Data are given as mean \pm standard deviation. Statistical significance required a $\mathrm{p}<0.05$.

\section{Results}

\section{Subject Characteristics}

A total of 98 of 265 obese patients (37\%) referred to our department met the inclusion criteria. Data from 48 controls were also analyzed. The demographic and anthropometric characteristics are presented in table 1. The mean age of control males was lower than that of obese males ( $32 \pm 11$ vs. $40 \pm 11$ years, $\mathrm{p}<0.05$ ), the range of values being not very different (21-60 years in controls, and $21-65$ years in obese patients). Since $\mathrm{DL}_{\mathrm{CO}}$ was ex- 
Table 1. Baseline characteristics and pulmonary function results

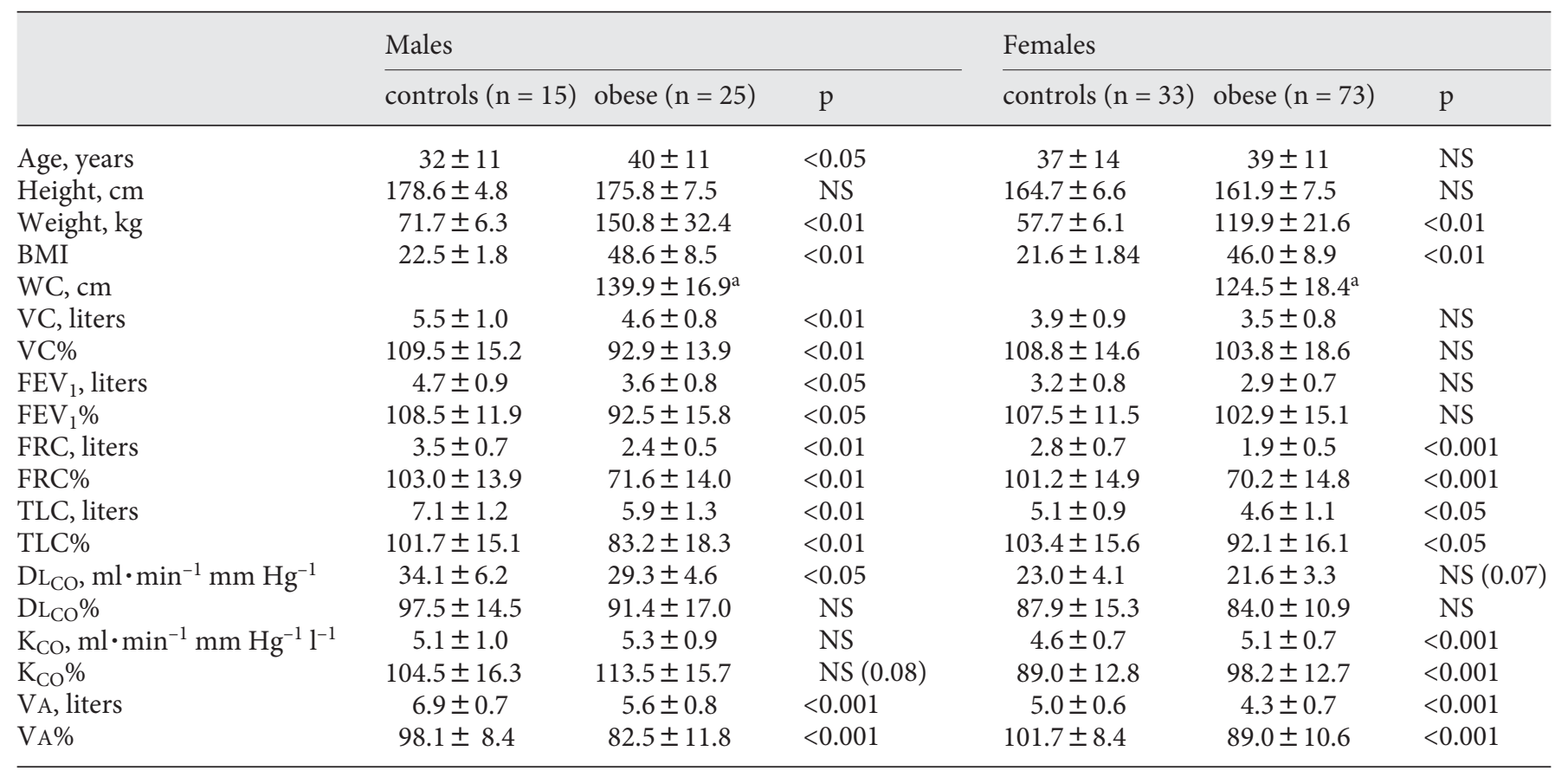

Results are presented as mean \pm SD. NS = Not significant; BMI = body mass index; WC = waist circumference; VC = vital capacity; $\mathrm{FEV}_{1}=$ forced expiratory volume in $1 \mathrm{~s} ; \mathrm{TLC}=$ total lung capacity. The pulmonary function values are given as absolute values and percentage of the predicted value.

a Obtained in 39 patients.

pressed in percent of predicted values based on age and height, this did not preclude comparisons between obese and control males. The $\mathrm{Hb}$ values of obese patients were $14.7 \pm 1.3$ in males and $13.4 \pm 1.1 \mathrm{~g} \cdot \mathrm{dl}^{-1}$ in females. Therefore, there was no difference between the corrected and the uncorrected $\mathrm{DL}_{\mathrm{CO}}$ values, which are calculated by the device with default $\mathrm{Hb}$ values of 14.6 in males and 13.5 in females.

\section{$D L_{C O}, V A$ and $K_{C O}$ in Obese Patients and Controls Using Conventional Reference Values}

Mean $\mathrm{DL}_{\mathrm{CO}} \%$ and VA\% were significantly lower in obese patients than in controls $(-6 \%, \mathrm{p}<0.05$ and $-13 \%$, $\mathrm{p}<0.001$, respectively). In contrast, $\mathrm{K}_{\mathrm{CO}} \%$ was higher in the obese group (+9\%, p $<0.05$; table 1$)$. The 23 obese patients with higher $\mathrm{DL}_{\mathrm{CO}} \%\left(>\right.$ mean $\mathrm{DL}_{\mathrm{CO}} \%$ of the control group) had VA\% of $97 \pm 9 \%$ of predicted values, not different from that of controls, and $\mathrm{K}_{\mathrm{CO}} \%$ of $112 \pm 15 \%$ of predicted values, higher than that of controls $(\mathrm{p}<0.01)$. The 33 obese patients with lower $\mathrm{DL}_{\mathrm{CO}} \%(<90 \%$ mean $\mathrm{DL}_{\mathrm{CO}} \%$ of the control group) had $\mathrm{VA} \%$ of $81 \pm 12 \%$ of predicted values, lower than that of controls $(\mathrm{p}<0.01)$ and $\mathrm{K}_{\mathrm{CO}} \%$ of $95 \pm 15 \%$ of predicted values, not different from that of controls.

\section{Relationship between $D L_{C O}, K_{C O}$ or VA and BMI or WC}

In the obese group, VA\% was inversely correlated with BMI ( $\mathrm{r}=-0.38, \mathrm{p}<0.001$; fig. 1$)$. $\mathrm{K}_{\mathrm{CO}} \%$ was correlated with BMI $(\mathrm{r}=0.32, \mathrm{p}<0.005)$. There was no correlation between $\mathrm{DL}_{\mathrm{CO}} \%$ and BMI. In obese men, $\mathrm{VA} \%$ was inversely correlated with $\mathrm{BMI}(\mathrm{r}=-0.60, \mathrm{p}<0.005), \mathrm{K}_{\mathrm{CO}} \%$ was not correlated with $\mathrm{BMI}$, and $\mathrm{DL}_{\mathrm{CO}} \%$ tended to be inversely correlated with BMI $(\mathrm{r}=-0.38, \mathrm{p}=0.06)$. In obese women, VA\% was inversely correlated with BMI $(\mathrm{r}=-0.28, \mathrm{p}<0.05) . \mathrm{K}_{\mathrm{CO}} \%$ was correlated with BMI $(\mathrm{r}=0.38, \mathrm{p}<0.05)$, and there was no correlation between $\mathrm{DL}_{\mathrm{CO}} \%$ and $\mathrm{BMI}$. In the control group, there was no correlation between $\mathrm{BMI}$ and either $\mathrm{DL}_{\mathrm{CO}} \%, \mathrm{~K}_{\mathrm{CO}} \%$ or $\mathrm{VA} \%$.

VA\% was inversely correlated with WC $(\mathrm{r}=-0.45, \mathrm{p}<$ $0.01) . \mathrm{K}_{\mathrm{CO}} \%$ was correlated with $\mathrm{WC}(\mathrm{r}=0.60, \mathrm{p}<0.0001)$. There was no correlation between $\mathrm{DL}_{\mathrm{CO}} \%$ and WC. 


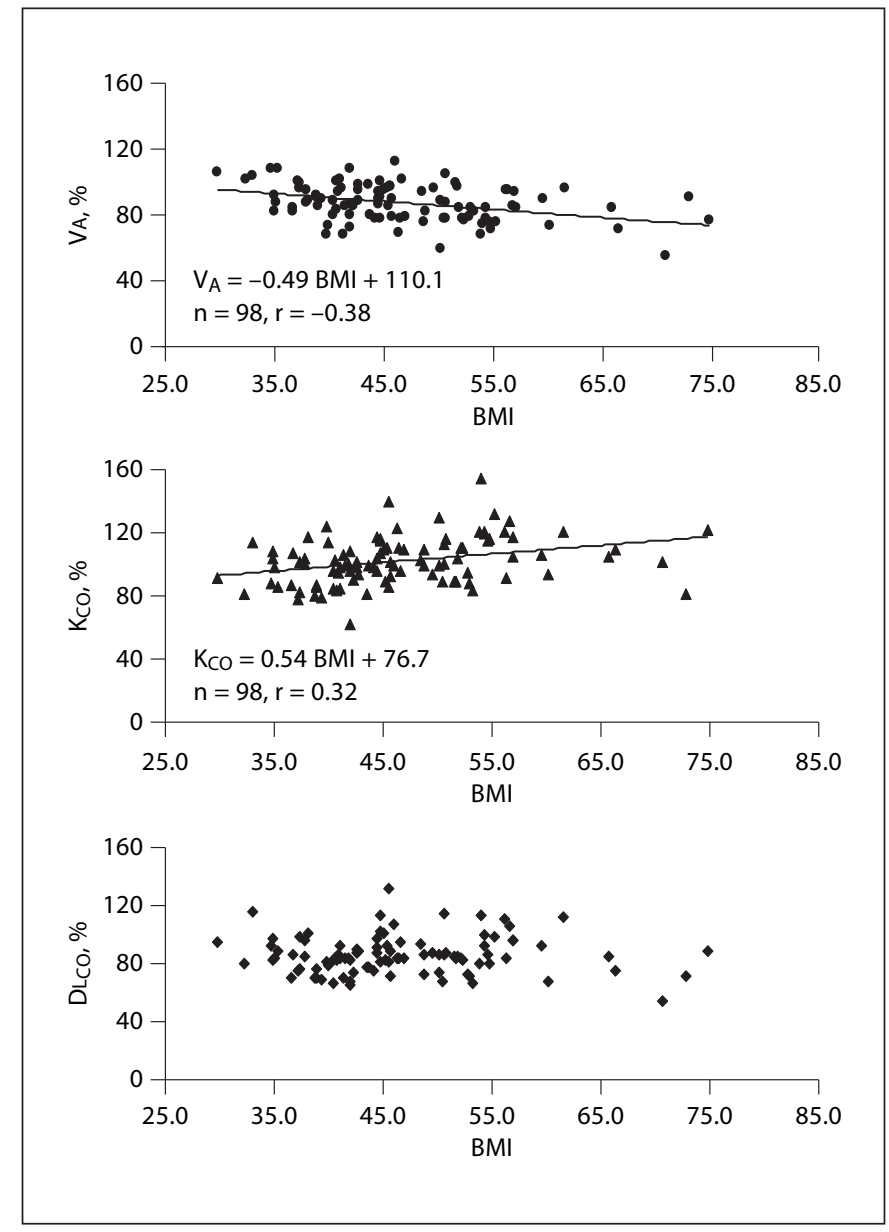

Fig. 1. Relationship between $\mathrm{VA}, \mathrm{K}_{\mathrm{CO}}$ or $\mathrm{DL}_{\mathrm{CO}}$ (expressed in percentage of ERS predicted values [17]), and body mass index (BMI) in 98 obese patients.

\section{$D L_{C O}$ Values Adjusted for VA}

Results are presented in table 2 . There was no difference between obese patients and controls using these reference equations. Using the equations of Chinn et al. [14], $10 \%$ of obese women and $16 \%$ of obese men had $\mathrm{DL}_{\mathrm{CO}}$ adjusted for $\mathrm{VA}$ of $<80 \%$, and $4 \%$ of women and $8 \%$ of men had $\mathrm{DL}_{\mathrm{CO}}$ adjusted for VA of $>110 \%$. Using the equations of Stam et al. [13], 18\% of obese women and $20 \%$ of obese men had $\mathrm{K}_{\mathrm{CO}}$ adjusted for VA of $<80 \%$, and $2 \%$ of women and $4 \%$ of men had $\mathrm{K}_{\mathrm{CO}}$ adjusted for VA of $>110 \%$.

\section{Discussion}

\section{$D L_{C O}, K_{C O}$ and VA in Obese Patients and Controls} Using Conventional Reference Values

In our group of 98 obese patients, mean $\mathrm{DL}_{\mathrm{CO}} \%$ was slightly but significantly lower (-6\%) than that in the control group. A low VA\% (-13\% compared to controls) likely explains the lower $\mathrm{DL}_{\mathrm{CO}} \%$ in our obese patients. This hypothesis is supported by several studies in which $\mathrm{DL}_{\mathrm{CO}}$ and VA were measured in obese patients at rest [22], during exercise [23] or after weight loss [10]. Although VA was inversely correlated with BMI (fig. 1), we found no correlation between $\mathrm{DL}_{\mathrm{CO}}$ and BMI. This is likely the result of the positive correlation between $\mathrm{K}_{\mathrm{CO}}$ and $\mathrm{BMI}$ and the inverse correlation between VA and BMI (fig. 1). The impact of VA on $\mathrm{DL}_{\mathrm{CO}}$ could be identified as this series included a large proportion of very obese patients who demonstrate the largest loss of VA. Indeed, 77 of 98 pa-

Table 2. $\mathrm{DL}_{\mathrm{CO}}$ values adjusted for alveolar volumes

\begin{tabular}{|c|c|c|c|c|c|c|}
\hline & \multicolumn{3}{|l|}{$\mathrm{DL}_{\mathrm{CO}} \%$} & \multicolumn{3}{|l|}{$\mathrm{K}_{\mathrm{CO}} \%$} \\
\hline & Chinn et al. [14] & Johnson et al. [16] & Frans et al. [12] & Frans et al. [12] & Stam et al. [13] & Filley et al. [15] \\
\hline Obese males & $\begin{array}{c}91.1 \pm 13.8 \\
(63.3-121.9)\end{array}$ & $\begin{array}{l}108.3 \pm 6.0 \\
(98.3-123.5)\end{array}$ & $\begin{array}{c}95.3 \pm 14.9 \\
(64.3-131.7)\end{array}$ & $\begin{array}{l}103.1 \pm 15.9 \\
(66.8-138.9)\end{array}$ & $\begin{array}{c}86.9 \pm 11.9 \\
(62.6-110.3)\end{array}$ & $\begin{array}{c}88.6 \pm 8.3 \\
(67.5-102.3)\end{array}$ \\
\hline Control males & $\begin{array}{c}91.9 \pm 14.2 \\
(72.0-128.8)\end{array}$ & $\begin{array}{c}101.7 \pm 3.1 \\
96.0-106.9)\end{array}$ & $\begin{array}{c}97.5 \pm 14.4 \\
(77.1-135.5)\end{array}$ & $\begin{array}{l}102.1 \pm 16.0 \\
(83.5-142.2)\end{array}$ & $\begin{array}{c}89.9 \pm 14.1 \\
(70.4-126.5)\end{array}$ & $\begin{array}{c}97.7 \pm 4.3 \\
(90.5-105.5)\end{array}$ \\
\hline Obese females & $\begin{array}{c}92.9 \pm 10.0 \\
(68.1-118.0)\end{array}$ & $\begin{array}{l}105.0 \pm 4.8 \\
(95.1-115.6)\end{array}$ & $\begin{array}{c}86.0 \pm 9.8 \\
(63.0-111.5)\end{array}$ & $\begin{array}{c}92.4 \pm 11.5 \\
(61.0-120.2)\end{array}$ & $\begin{array}{c}91.9 \pm 10.7 \\
(65.9-118.9)\end{array}$ & $\begin{array}{c}93.1 \pm 6.7 \\
(78.5-106.8)\end{array}$ \\
\hline Control females & $\begin{array}{c}91.4 \pm 13.6 \\
(70.8-126.7)\end{array}$ & $\begin{array}{l}99.4 \pm 3.5 \\
(94.4-108.6)\end{array}$ & $\begin{array}{c}86.6 \pm 13.5 \\
(68.3-122.8)\end{array}$ & $\begin{array}{c}96.8 \pm 3.2 \\
(86.9-99.6)\end{array}$ & $\begin{array}{c}89.4 \pm 14.6 \\
(69.6-124.7)\end{array}$ & $\begin{array}{l}100.8 \pm 4.9 \\
(88.2-107.8)\end{array}$ \\
\hline
\end{tabular}

Results are expressed as mean \pm standard deviation (range). The reference values used to adjust $\mathrm{DL}_{\mathrm{CO}}$ or $\mathrm{K}_{\mathrm{CO}}$ for $\mathrm{VAs}_{\mathrm{s}}$ are those published by Chinn et al. [14], Frans et al. [12], Johnson et al. [16], Stam et al. [13] and Filley et al. [15]. 
tients $(79 \%)$ had a BMI of $>40$. Interestingly, obese patients presented with a large range of $\mathrm{DL}_{\mathrm{CO}} \%$ values, from 65 to $114 \%$. Our 33 patients with lower $\mathrm{DL}_{\mathrm{CO}} \%$ had low $\mathrm{VA} \%$, and these low VA\% were not, as was expected, coupled with high $\mathrm{K}_{\mathrm{CO}} \%$. On the other hand, the 23 obese patients with higher $\mathrm{DL}_{\mathrm{CO}}$ showed a high $\mathrm{K}_{\mathrm{CO}} \%$ together with VA\% very close to our control VA\%. Whether the preservation of normal lung volume in obese patients is associated with specific fat distribution deserves to be investigated. Taken as a whole, these results illustrate that, using conventional reference equations, obese patients can present with a variety of $\mathrm{DL}_{\mathrm{CO}}$ values and patterns.

\section{$D L_{C O}$ and $K_{C O}$ in Obese Patients and Controls Using}

Reference Values Adjusted for VA

Several reference equations have been established to adjust $\mathrm{DL}_{\mathrm{CO}}$ and $\mathrm{K}_{\mathrm{CO}}$ for lung volume. We used some of these equations [12-16] in our series and found that mean adjusted $\mathrm{DL}_{\mathrm{CO}}$ values were similar in the obese and control groups. This suggests that altered lung volumes explain most of $\mathrm{DL}_{\mathrm{CO}}$ variations in obese patients. This conclusion, however, is based on the assumption that the $\mathrm{K}_{\mathrm{CO}}$-VA relationship does not differ significantly in normal subjects and in obese patients, since the VA effects on $\mathrm{DL}_{\mathrm{CO}}$ were derived from studies in normal subjects with submaximal inspiratory volumes. Increased abdominal pressure and mechanical constraint placed on the chest wall by fat accumulation are the main mechanisms leading to low lung volumes in obesity [23]. No structural pulmonary abnormalities have been described, and normalization of lung function after weight loss has been reported. Therefore, one may hypothesize that the $\mathrm{K}_{\mathrm{CO}}-\mathrm{VA}$ relationship is not significantly modified in obesity. To further investigate this hypothesis, studying the contribution to lung diffusion capacity of the distribution of gas and perfusion in the lungs of obese patients, especially in basal lung areas [24], should be of interest. In this view, comparing Krogh factors and lung volumes measured with the re-breathing and single breath methods at the same inspired volume should allow correcting diffusion for the effects of unequal ventilation in obese subjects [25, 26].

After adjustment of $\mathrm{DL}_{\mathrm{CO}}$ or $\mathrm{K}_{\mathrm{CO}}$ for lung volume, 10$20 \%$ of obese patients, according to the chosen equation, had values of $<80 \%$ of predicted. This may suggest that, in addition to low lung volumes, obesity-associated disorders may contribute to decrease diffusing capacity in some patients. In a recent study, $40 \%$ of obese patients with reduced $\mathrm{DL}_{\mathrm{CO}}$ presented with moderate or severe diastolic dysfunction, which may trigger disruption of the alveolar-capillary barrier [9]. Type 2 diabetes, which reduces alveolar microvascular reserves and lung volumes, may also impair diffusing capacity in obese patients [27].

Using adjusted $\mathrm{DL}_{\mathrm{CO}} \%$ or $\mathrm{K}_{\mathrm{CO}} \%$ values for $\mathrm{VA}$, we found very few obese patients (2-8\% according to the reference equation) with high $\mathrm{DL}_{\mathrm{CO}} \%$ or $\mathrm{K}_{\mathrm{CO}} \%$ values. High $\mathrm{K}_{\mathrm{CO}}$ in obesity has been attributed to larger total circulating blood volume that increases pulmonary vascular recruitment [28]. The last assumption has received particular attention and was supported by the finding of an increased capillary volume in severely obese patients using the Roughton and Forster method [8]. Another author achieved similar conclusions using the diffusing capacity for nitric oxide [10]. However, both authors found diminished membrane diffusion that counterbalanced the high capillary volume and lead to normal $\mathrm{DL}_{\mathrm{CO}}$ values in their obese patients.

\section{Limitations of the Study and Perspectives}

Larger series of obese patients are needed to study the role of fat distribution on VA and $\mathrm{DL}_{\mathrm{CO}}$. In this view, WC may be a better predictor of $\mathrm{DL}_{\mathrm{CO}}$ than $\mathrm{BMI}$ since it reflects central adiposity $[29,30]$. In addition, the small sexrelated differences we observed (tendency of $\mathrm{DL}_{\mathrm{CO}}$ to decrease with BMI and lack of correlation between $\mathrm{K}_{\mathrm{CO}}$ and BMI in men, in contrast to women) suggest that there may be a larger loss of lung function in obese men compared to women which deserves to be confirmed [31,32]. In further series, particular attention should also be paid to patients $>60$ years, since VA dependence of $\mathrm{DL}_{\mathrm{CO}}$ has been found to be larger in younger subjects [13].

In conclusion, using conventional reference equations, our series of very obese patients shows slightly lower $\mathrm{DL}_{\mathrm{CO}}$, lower VA and higher $\mathrm{K}_{\mathrm{CO}}$ than controls, with subtle gender differences. However, the range of $\mathrm{DL}_{\mathrm{CO}}$ values is large, from low $\mathrm{DL}_{\mathrm{CO}}$ characterized by low $\mathrm{VA}$ and $\mathrm{K}_{\mathrm{CO}}$, to high-normal $\mathrm{DL}_{\mathrm{CO}}$ characterized by normal $\mathrm{VA}$ and high $\mathrm{K}_{\mathrm{CO}}$. Using reference equations adjusting $\mathrm{DL}_{\mathrm{CO}}$ for $\mathrm{VA}$, the differences between the obese and the control groups disappear, suggesting that low lung volumes are the main cause of low $\mathrm{DL}_{\mathrm{CO}}$ and high $\mathrm{K}_{\mathrm{CO}}$ values in obese patients. These results may help to better understand lung function in very obese patients in clinical situations of increasing frequency, such as pre-bariatric surgery assessment. 


\section{References}

$>1$ McClean KM, Kee F, Young IS, Elborn JS: 14 Chinn DJ, Cotes JE, Flowers R, Marks AM, Obesity and the lung: 1 . Epidemiology. Tho$\operatorname{rax} 2008 ; 63: 649-654$.

$>2$ Collard P, Wilputte JY, Aubert G, Rodenstein DO, Frans A: The single-breath diffusing capacity for carbon monoxide in obstructive sleep apnea and obesity. Chest 1996;110:1189-1193.

-3 Ray CS, Sue DY, Bray G, Hansen JE, Wasserman K: Effects of obesity on respiratory function. Am Rev Respir Dis 1983;128:501506.

4 Saydain G, Beck KC, Decker PA, Cowl CT, Scanlon PD: Clinical significance of elevated diffusing capacity. Chest 2004;125:446-452.

$>5$ Biring MS, Lewis MI, Liu JT, Mohsenifar Z: Pulmonary physiologic changes of morbid obesity. Am J Med Sci 1999;318:293-297.

$\checkmark 6$ Jones RL, Nzekwu MM: The effects of body mass index on lung volumes. Chest 2006; 130:827-833.

7 Hakala K, Stenius-Aarniala B, Sovijarvi A: Effects of weight loss on peak flow variability, airways obstruction, and lung volumes in obese patients with asthma. Chest 2000;118: 1315-1321.

$>8$ Oppenheimer BW, Berger KI, Rennert DA, Pierson RN, Norman RG, Rapoport DM, Kral JG, Goldring RM: Effect of circulatory congestion on the components of pulmonary diffusing capacity in morbid obesity. Obesity (Silver Spring) 2006;14:1172-1180.

$>9$ Ravipati G, Aronow WS, Sidana J, Maguire GP, McClung JA, Belkin RN, Lehrman SG: Association of reduced carbon monoxide diffusing capacity with moderate or severe left ventricular diastolic dysfunction in obese persons. Chest 2005;128:1620-1622.

10 Zavorsky GS, Kim do J, Sylvestre JL, Christou NV: Alveolar-membrane diffusing capacity improves in the morbidly obese after bariatric surgery. Obes Surg 2008;18:256263.

11 Hughes JM, Pride NB: In defence of the carbon monoxide transfer coefficient $\mathrm{K}_{\mathrm{CO}}$ (TL/ VA). Eur Respir J 2001;17:168-174.

$>12$ Frans A, Nemery B, Veriter C, Lacquet L, Francis C: Effect of alveolar volume on the interpretation of single breath $\mathrm{DL}_{\mathrm{CO}}$. Respir Med 1997;91:263-273.

13 Stam H, Hrachovina V, Stijnen T, Versprille A: Diffusing capacity dependent on lung volume and age in normal subjects. J Appl Physiol 1994;76:2356-2363.
Reed JW: Transfer factor (diffusing capacity) standardized for alveolar volume: validation, reference values and applications of a new linear model to replace $\mathrm{K}_{\mathrm{CO}}$ (TL/VA). Eur Respir J 1996;9:1269-1277.

15 Filley GF, Macintosh DJ, Wright GW: Carbon monoxide uptake and pulmonary diffusing capacity in normal subjects at rest and during exercise. J Clin Invest 1954;33:530 539.

16 Johnson DC: Importance of adjusting carbon monoxide diffusing capacity (DLCO) and carbon monoxide transfer coefficient (KCO) for alveolar volume. Respir Med 2000;94:28-37.

17 Cotes JE, Chinn DJ, Quanjer PH, Roca J, Yernault JC: Standardization of the measurement of transfer factor (diffusing capacity). Work Group on Standardization of Respiratory Function Tests. European Community for Coal and Steel. Official position of the European Respiratory Society (in French). Rev Mal Respir 1994;11(suppl 3):41-52.

18 Macintyre N, Crapo RO, Viegi G, Johnson DC, van der Grinten CP, Brusasco V, Burgos F, Casaburi R, Coates A, Enright P, Gustafsson P, Hankinson J, Jensen R, McKay R, Miller MR, Navajas D, Pedersen OF, Pellegrino R, Wanger J: Standardisation of the singlebreath determination of carbon monoxide uptake in the lung. Eur Respir J 2005;26:720735.

19 Miller MR, Hankinson J, Brusasco V, Burgos F, Casaburi R, Coates A, Crapo R, Enright P, van der Grinten CP, Gustafsson P, Jensen R, Johnson DC, MacIntyre N, McKay R, Navajas D, Pedersen OF, Pellegrino R, Viegi G, Wanger J: Standardisation of spirometry. Eur Respir J 2005;26:319-338.

20 Wanger J, Clausen JL, Coates A, Pedersen OF, Brusasco V, Burgos F, Casaburi R, Crapo $\mathrm{R}$, Enright P, van der Grinten CP, Gustafsson P, Hankinson J, Jensen R, Johnson D, Macintyre N, McKay R, Miller MR, Navajas D, Pellegrino R, Viegi G: Standardisation of the measurement of lung volumes. Eur Respir J 2005;26:511-522.

21 Quanjer PH, Tammeling GJ, Cotes JE, Pedersen OF, Peslin R, Yernault JC: Lung volumes and forced ventilatory flows. Report Working Party Standardization of Lung Function Tests, European Community for Steel and Coal. Official Statement of the European Respiratory Society. Eur Respir J 1993; 16:5-40.

-22 Zavorsky GS, Cao J, Murias JM: Reference values of pulmonary diffusing capacity for nitric oxide in an adult population. Nitric Oxide 2008;18:70-79.
23 Zavorsky GS, Kim do J, McGregor ER, Starling JM, Gavard JA: Pulmonary diffusing capacity for nitric oxide during exercise in morbid obesity. Obesity (Silver Spring) 2008; 16:2431-2438.

24 Holley HS, Milic-Emili J, Becklake MR, Bates DV: Regional distribution of pulmonary ventilation and perfusion in obesity. J Clin Invest 1967;46:475-481.

25 Jansons H, Fokkens JK, Tweel van der I, Lammers JW, Folgering $\mathrm{H}$ : Influence of unequal ventilation on the single breath $\mathrm{K}(\mathrm{CO})$ in COPD revealed by comparison with the rebreathing K(CO). Respir Physiol Neurobiol 2002;133:109-119.

-26 Jansons H, Fokkens JK, van der Tweel I, Kreukniet J: Rebreathing $\mathrm{K}(\mathrm{CO})$ and single breath $\mathrm{K}(\mathrm{CO})$ measured at the same mean alveolar volume reveal a physiological relationship between unequal diffusion and unequal ventilation in normal subjects. Respiration 2000;67:383-388.

27 Chance WW, Rhee C, Yilmaz C, Dane DM, Pruneda ML, Raskin P, Hsia CC: Diminished alveolar microvascular reserves in type 2 diabetes reflect systemic microangiopathy. Diabetes Care 2008;31:1596-1601.

28 Zavorsky GS: Pulmonary gas exchange and diffusing capacity at rest and during exercise in those with morbid obesity: pre- and postsurgical intervention; in Parsons WV, Taylor CM (eds): New Research on Morbid Obesity. New York, Nova Science, 2008, pp 117-150.

29 Chen Y, Rennie D, Cormier YF, Dosman J: Waist circumference is associated with pulmonary function in normal-weight, overweight, and obese subjects. Am J Clin Nutr 2007;85:35-39.

30 Ochs-Balcom HM, Grant BJ, Muti P, Sempos CT, Freudenheim JL, Trevisan M, Cassano PA, Iacoviello L, Schunemann HJ: Pulmonary function and abdominal adiposity in the general population. Chest 2006;129:853862 .

31 Zavorsky GS, Christou NV, Kim do J, Carli F, Mayo NE: Preoperative gender differences in pulmonary gas exchange in morbidly obese subjects. Obes Surg 2008;18:15871598.

32 Bottai M, Pistelli F, Di Pede F, Carrozzi L, Baldacci S, Matteelli G, Scognamiglio A, Viegi G: Longitudinal changes of body mass index, spirometry and diffusion in a general population. Eur Respir J 2002;20:665-673. 